\title{
Neuroestrogen-Dependent Transcriptional Activity in the Brains of ERE-Luciferase Reporter Mice following Short- and Long-Term Ovariectomy
}

\author{
Nina E. Baumgartner, ${ }^{1,2}$ Elin M. Grissom, ${ }^{1,3^{*}}$ Kevin J. Pollard, ${ }^{1,2}$ Shannon M. McQuillen, ${ }^{1,2}$ and Jill M. \\ Daniel ${ }^{1,2,3}$
}

https://doi.org/10.1523/ENEURO.0275-19.2019

${ }^{1}$ Neuroscience Program, ${ }^{2}$ Tulane Brain Institute, and ${ }^{3}$ Department of Psychology, Tulane University, New Orleans, Louisiana 70118

\section{Visual Abstract}

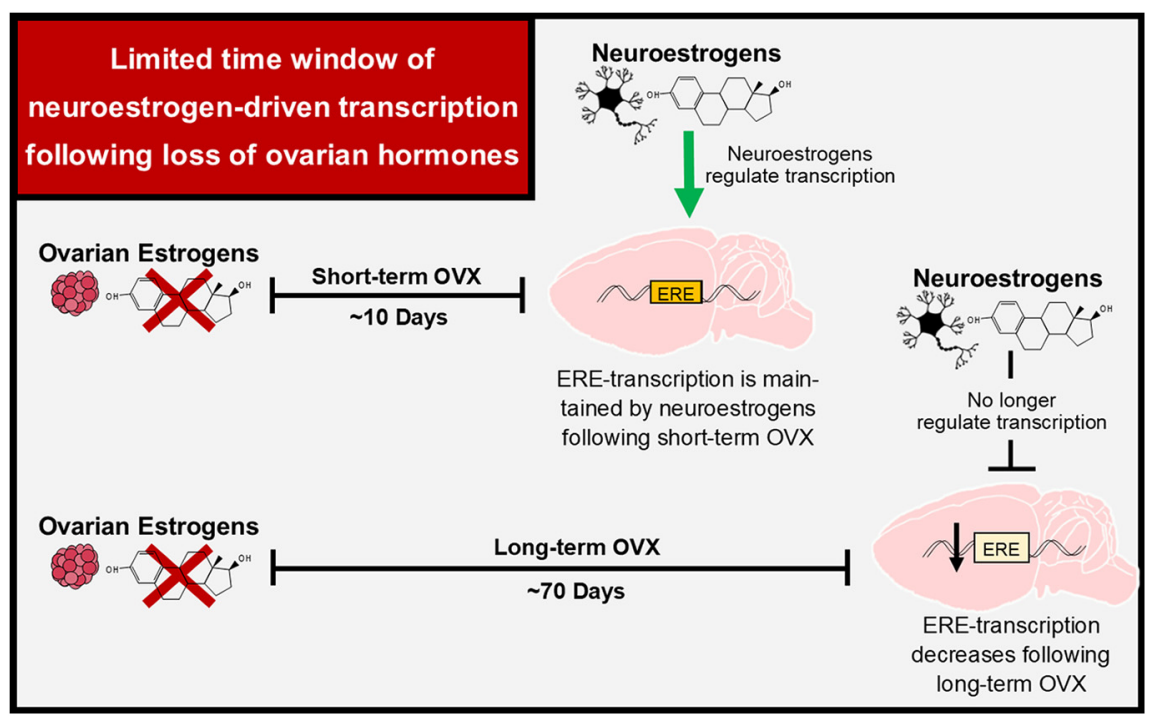

Previous work has demonstrated that estrogen receptors are transcriptionally active in the absence of ovarian estrogens. The current work aims to determine whether brain-derived estrogens influence estrogen receptordependent transcription after short- or long-term loss of ovarian function. Experiments were conducted using

\section{Significance Statement}

Impacts of circulating estrogens on the brain and behavior are widespread and well documented. More recently, the role of neuroestrogens has become a topic of interest. However, the relative contributions of neuroestrogens and ovarian estrogens to estrogen receptor activity in the brain remain unclear, particularly when considering the decline in ovarian estrogens during aging. Previous studies indicate that ovarian estrogens regulate neuroestrogen synthesis in the brain. Therefore, identifying actions of neuroestrogens following the loss of ovarian function is crucial to understanding estrogen receptor function in the brain. Here we demonstrate that estrogen receptors remain transcriptionally active in the brain following long-term loss of ovarian hormones. Neuroestrogens mediate that transcriptional activity for only a limited time following ovariectomy. 
estrogen response element (ERE)-Luciferase reporter mice, which express the gene for luciferase driven by consensus ERE, allowing for the quantification of ERE-dependent transcription. Brain regions examined were hippocampus, cortex, and hypothalamus. In Experiment 1, short-term (10 d) ovariectomy had no impact on ERE-dependent transcription across brain regions compared with sham surgery. In Experiment 2, chronic intracerebroventricular administration of the aromatase inhibitor letrozole significantly decreased transcriptional activity in 10-d-old ovariectomized mice across brain regions, indicating that the sustained transcription in short-term ovariectomized mice is mediated at least in part via actions of neuroestrogens. Additionally, intracerebroventricular administration of estrogen receptor antagonist ICl-182,780 blocked transcription in 10-d-old ovariectomized mice across brain regions, providing evidence that sustained transcription in ovariectomized mice is estrogen receptor dependent. In Experiment 3, long-term (70 d) ovariectomy significantly decreased EREdependent transcription across brain regions, though some residual activity remained. In Experiment 4, chronic intracerebroventricular letrozole administration had no impact on transcription in $70 \mathrm{~d}$ ovariectomized mice across brain regions, indicating that the residual ERE-dependent transcription in long-term ovariectomized mice is not mediated by neuroestrogens. Overall, the results indicate that ERE-dependent transcription in the brain continues after ovariectomy and that the actions of neuroestrogens contribute to the maintenance of ERE-dependent transcription in the brain following short-term, but not long-term, loss of ovarian function.

Key words: cortex; estradiol; estrogen; hippocampus; hypothalamus; neuroestrogen

\section{Introduction}

Decades of research have shown that estrogens impact cognition by binding to estrogen receptors (ERs) in the brain (Luine, 2014; Daniel et al., 2015; Korol and Pisani, 2015). Nuclear steroid estrogen receptors $\alpha$ and $\beta$ are expressed throughout the brain, including in the hypothalamus, hippocampus, and cortical areas across species (Shughrue et al., 1997; Mitra et al., 2003; González et al., 2007). Estrogen receptors classically act as transcription factors, binding to estrogen response elements (EREs) to promote transcriptional changes (Hyder et al., 1999). They can also rapidly activate intracellular cascades to impact cellular function on a faster time scale (Luine et al., 2018). Because of the well established impacts of estrogen on learning and memory, much research has focused on the role of estrogen receptors in the hippocampus (Bean et al., 2014). Importantly, hippocampal estrogen receptors have been shown to impact memory (Witty et al., 2012) and act in a transcriptional capacity (Pollard et al., 2018) in the absence of circulating estrogens.

Received July 8, 2019; accepted September 22, 2019; First published October 1, 2019.

The authors declare no competing financial interests.

Author contributions: N.E.B., E.M.G., K.J.P., and J.M.D. designed research; N.E.B., E.M.G., K.J.P., and S.M.M. performed research; N.E.B., E.M.G., and K.J.P. analyzed data; N.E.B. and J.M.D. wrote the paper.

This work was supported by Grant RF1-AG-041374 from the National Institute on Aging (to J.M.D.) and Grant K12-HD-043451 from the National Institutes of Health Office for Research in Women's Health BIRCWH (Building Interdisciplinary Research Careers in Women's Health) program (to E.M.G.).

${ }^{*}$ N.E.B. and E.M.G. are co-first authors.

E. M. Grissom's present address: Department of Psychological Sciences, Loyola University New Orleans, 70118.

Acknowledgments: We thank Amy Pierce, Associate Director Uptown Campus of the Tulane Department of Comparative Medicine, and the vivarium staff for expert animal care.

Correspondence should be addressed to Nina E. Baumgartner at Nbaumgar@tulane.edu.

https://doi.org/10.1523/ENEURO.0275-19.2019

Copyright (C) 2019 Baumgartner et al.

This is an open-access article distributed under the terms of the Creative Commons Attribution 4.0 International license, which permits unrestricted use, distribution and reproduction in any medium provided that the original work is properly attributed.
The discovery of brain-derived estrogens has provided a new direction for studying the mechanisms of estrogen receptor activity in the brain. The hippocampus is capable of de novo synthesis of estradiol (Prange-Kiel et al., 2003), the main estrogen produced by the ovaries. Other brain regions are known to contain aromatase-the enzyme that converts testosterone to estradiol-including the amygdala, the bed nucleus of stria terminalis, the hypothalamus, and the cerebral cortex (Naftolin et al., 1996; Azcoitia et al., 2011; Stanić et al., 2014; Tabatadze et al., 2014). Locally produced neuroestrogens have been implicated in many aspects of brain function, including hippocampal synaptic plasticity (Kretz et al., 2004), gonadotropin-releasing hormone $(\mathrm{GnRH})$ release from the hypothalamus (Kenealy et al., 2013), and catecholaminergic regulation in the prefrontal cortex (Kokras et al., 2018). Although identical in structure to ovarian estrogens, neuroestrogens appear to act on membrane-bound estrogen receptors to induce rapid changes within cells (Ishii et al., 2007; Wang et al., 2018). It is unknown whether neuroestrogens might also induce genomic actions of nuclear estrogen receptors in the brain, although the rapid actions of membrane estrogen receptors may ultimately lead to transcriptional effects (Lai et al., 2017).

Neuroestrogen synthesis appears to be regulated by circulating estrogens, either produced by the ovaries or given exogenously, via feedback through $\mathrm{GnRH}$ neurons in the hypothalamus (Prange-Kiel et al., 2013). In rats, the inhibition of estradiol synthesis in the hippocampus blocks the memory-enhancing effects of systemic estradiol treatment, indicating that the effects of systemic estradiol are mediated through locally produced estradiol (Nelson et al., 2016). In mice, estrogen receptors in the brain remain transcriptionally active after loss of systemic estrogens (Pollard et al., 2018), but it is unclear whether neuroestrogens can activate these receptors in the absence of systemic estrogens. Studies using aromatase inhibitors in recently ovariectomized rodents indicate that neuroestrogens rapidly activate estrogen receptors for at least some period of time following ovariectomy (Tuscher 
et al., 2016). Ovariectomy in rats reduced brain estradiol levels in the hippocampus, but not in the cortex or amygdala, suggesting a brain region-specific regulation of neuroestrogen synthesis following ovariectomy (Barker and Galea, 2009). Due to the regulatory relationship between circulating estrogens and neuroestrogen synthesis, we hypothesize that the contribution of neuroestrogens to estrogen receptor activation following the loss of ovarian hormones would decrease over time.

The goal of the current project was to test the hypothesis that brain-derived estrogens impact estrogen receptor-dependent transcriptional activity in the brain following short-term, but not long-term, loss of ovarian function. To test this hypothesis, we completed four experiments using the ERE-Luciferase (ERE-Luc) reporter mouse model, which expresses the gene for the firefly enzyme luciferase under the control of consensus ERE sequences (Ciana et al., 2001). In Experiment 1, we measured luciferase activity in the uteri and brains of gonadally intact or short-term ( $\sim 10$ d) ovariectomized ERE-Luc mice to determine whether ERE-dependent transcription decreases following short-term ovariectomy. In Experiment 2, we administered the aromatase inhibitor letrozole to brains of short-term ovariectomized ERE-Luc mice to determine whether neuroestrogens impact ERE-dependent transcription following short-term ovariectomy. Additionally, we administered the estrogen receptor antagonist ICl 182,780 (ICl) to verify that observed transcription was estrogen receptor dependent. In Experiment 3, we measured luciferase activity in brains of gonadally intact or long-term ( $\sim 70$ d) ovariectomized ERE-Luc mice to determine whether ERE-dependent transcription decreases following long-term ovariectomy. Finally, in Experiment 4, we administered letrozole to brains of longterm ovariectomized ERE-Luc mice to determine whether neuroestrogens impact ERE-dependent transcription following long-term loss of ovarian hormones.

\section{Materials and Methods}

\section{Subjects}

Adult female heterozygous ERE-Luc model mice ( $\sim 70 \mathrm{~d}$ of age) were obtained from Charles River Laboratories for Experiments 1 and 2. Adult female heterozygous ERE-Luc model mice (70-110 d of age) were obtained from our onsite breeding colony for Experiments 3 and 4 . Animals were group housed in a temperature-controlled AAALACaccredited vivarium under a $12 \mathrm{~h}$ light/dark cycle with ad libitum access to phytoestrogen-free food and water. Animal care was performed in accordance with guidelines set by the National Institutes of Health Guide for the Care and Use of Laboratory Animals (2011). All animal procedures were performed in accordance with the regulations of the Tulane University animal care committee.

\section{Ovariectomy surgeries}

Mice underwent either ovariectomy (Experiment 1,n = 5; Experiment 2, $n=12$; Experiment 3, $n=5$; Experiment $4, n=14$ ) or sham surgery (Intact; Experiment 1, $n=5$; Experiment 2, $n=4$; Experiment 3, $n=5$; Experiment 4, $n=7$ ) under anesthesia induced by intraperitoneal injec-
A

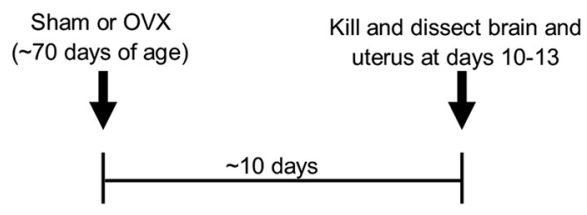

B

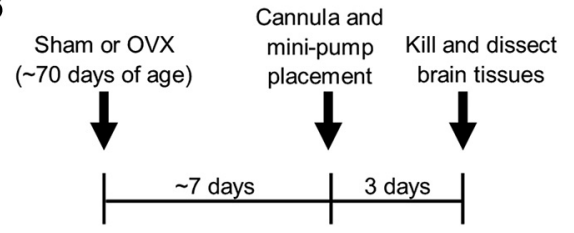

C

Sham or OVX

(70-110 days of age)
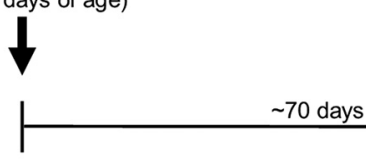

D

Sham or OVX

$(\sim 70$ days of age)

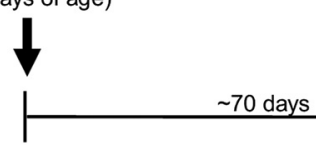

Cannula and

mini-pump Kill and dissect

mini-pump
placement brain tissues

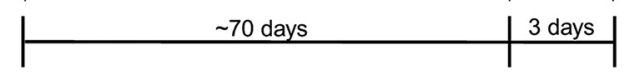

Figure 1. $\boldsymbol{A}-\boldsymbol{D}$, Experimental timelines for Experiment 1 (A), Experiment $2(\boldsymbol{B})$, Experiment $3(\boldsymbol{C})$, and Experiment $4(\boldsymbol{D})$. Sham, Sham surgery; OVX, ovariectomy.

tion of ketamine (100 mg/kg; Bristol Laboratories) and xylazine (7 mg/kg; MWl Animal Health). Ovariectomy surgeries involved bilateral flank incisions through the skin and muscle wall and the removal of ovaries. Sham surgeries involved bilateral flank incisions through the skin and muscle wall. Incisions were closed using sutures and wound clips. Buprenorphine $(0.375 \mathrm{mg} / \mathrm{kg}$; Reckitt Benckiser Health Care) was administered by subcutaneous injection before the start of each surgery. Mice were single housed following surgery. One OVX mouse from Experiment 3 was lost due to complications from anesthesia.

\section{Estrous cycle tracking}

The estrous cycles of gonadally intact mice were tracked every day starting $1 \mathrm{~d}$ (Experiments 1 and 2) or 55 $\mathrm{d}$ (Experiments 3 and 4) after sham or ovariectomy surgery and through the day they were killed using the estrous cycle identification tool described in the study by Byers et al. (2012). Experiments were planned such that the killing of the mice and tissue collection would occur on days that gonadally intact mice were in proestrus with pair-matched ovariectomized controls killed on the same days. See Figure $1 A-D$ for summaries of experiment timelines.

\section{Experiment 1}

Animals were killed on the first day of proestrus that occurred at least $10 \mathrm{~d}$ following sham surgery in the gonadally intact animal of each pair. 
Table 1: Experiment 1 statistics

\begin{tabular}{|c|c|c|c|c|c|c|c|}
\hline Figure & $\begin{array}{l}\text { Statistical } \\
\text { test }\end{array}$ & $\begin{array}{l}\text { Independent } \\
\text { variables }\end{array}$ & $\begin{array}{l}\text { Sample } \\
\text { size }\end{array}$ & Statistics & $\begin{array}{l}\text { Observed } \\
\text { power }\end{array}$ & $\begin{array}{l}\text { Post hoc } \\
\text { comparison } \\
\text { (if applicable) }\end{array}$ & $\begin{array}{l}\text { Post hoc } \\
\text { statistics }\end{array}$ \\
\hline \multirow[t]{4}{*}{$2 A$} & $\begin{array}{l}\text { Two-way } \\
\text { ANOVA }\end{array}$ & $\begin{array}{l}\text { Brain region (cortex, } \\
\text { hypothalamus, hippocampus) } \\
\text { Treatment (Intact, OVX) }\end{array}$ & $\begin{array}{l}\text { Cortex: } \\
\text { Intact } n=5 \\
\text { OVX } n=5 \\
\text { Hypothalamus: } \\
\text { Intact } n=4 \\
\text { OVX } n=4 \\
\text { Hippocampus: } \\
\text { Intact } n=4 \\
\text { OVX } n=5\end{array}$ & & & & \\
\hline & & $\begin{array}{l}\text { Main effect of } \\
\text { brain region }\end{array}$ & & $F_{(2,21)}=0.903 ; p=0.420$ & 0.0185 & & \\
\hline & & $\begin{array}{l}\text { Main effect } \\
\text { of treatment }\end{array}$ & & $F_{(1,21)}=0.780 ; p=0.387$ & 0.135 & & \\
\hline & & $\begin{array}{l}\text { Brain region } \times \\
\text { treatment interaction }\end{array}$ & & $F_{(2,21)}=0.903 ; p=0.420$ & 0.1845 & & \\
\hline $2 B$ & $\begin{array}{l}\text { One-way } \\
\text { ANOVA }\end{array}$ & Treatment (Intact, OVX) & $\begin{array}{l}\text { Intact } n=4 \\
\text { OVX } n=4\end{array}$ & $F_{(1,6)}=5.556 ; p=0.057$ & 0.624 & & \\
\hline
\end{tabular}

\section{Experiment 2}

Animals underwent stereotaxic surgery on the day after the first proestrus day that occurred at least $7 \mathrm{~d}$ following sham surgery in the gonadally intact animal of each pair. All mice were killed $3 \mathrm{~d}$ after stereotaxic surgery on days that gonadally intact mice were in proestrus.

\section{Experiment 3}

Animals were killed on the first day of proestrus that occurred at least $70 \mathrm{~d}$ following sham surgery in the gonadally intact animal of each pair.

\section{Experiment 4}

Animals underwent stereotaxic surgery on the day after the first proestrus day that occurred at least $67 \mathrm{~d}$ following sham surgery in the gonadally intact animal of each pair. All mice were killed $3 \mathrm{~d}$ after stereotaxic surgery on days that gonadally intact mice were in proestrus.

\section{Cannula and mini-pump implantations Experiment 2}

Mice were anesthetized with ketamine and xylazine as described above and administered buprenorphine as an analgesic. Mice were then placed into a stereotaxic frame. An incision was made in the scalp and fascia that overlie the skull. A hole was drilled in the skull, and a cannula (brain infusion kits, Alzet) was lowered through the hole to the appropriate depth to reach the right lateral ventricle (relative to bregma: anteroposterior, $-0.5 \mathrm{~mm}$; mediolateral, $-1.1 \mathrm{~mm}$; dorsoventral, $-2.5 \mathrm{~mm}$ ) and anchored to the skull with Super Glue and dental acrylic. The cannula was connected to an osmotic mini-pump (flow rate, 0.5 $\mu \mathrm{l} / \mathrm{h}$; Alzet) by vinyl tubing for drug delivery. Gonadally intact animals received vehicle $(n=4)$ containing $10 \%$ DMSO (Sigma-Aldrich) in artificial CSF (aCSF; Tocris Bioscience). Ovariectomized animals received vehicle $(n=4)$, the aromatase inhibitor letrozole $(0.1 \mu \mathrm{g} / \mu \mathrm{l}$; Bachem; $n=$ $4)$, or the estrogen receptor antagonist ICI 182,780 ( $n=4$; $0.3 \mu \mathrm{g} / \mu \mathrm{l}$; Sigma-Aldrich). The pump was implanted subcutaneously in the nape of the neck, and the cannula was inserted after the pump began pumping.

\section{Experiment 4}

Mice received a cannula directed to the right lateral ventricle connected to mini-pumps (flow rate, $0.5 \mu \mathrm{l} / \mathrm{h}$ ) in a procedure identical to that described in Experiment 2. Gonadally intact mice received mini-pumps that delivered vehicle $(n=7)$ containing $10 \%$ DMSO in aCSF. Ovariectomized mice received mini-pumps containing either vehicle $(n=7)$ or letrozole $(0.1 \mu \mathrm{g} / \mu \mathrm{l} ; n=7)$.

\section{Euthanasia and tissue processing}

All animals were anesthetized by intraperitoneal injection of ketamine and xylazine and were killed during the same time window (10:00 A.M. to 12:00 P.M.), which coincided with the timing of daily vaginal smears. The right hippocampus, hypothalamus, right parietal cortex, and uterus (Experiment 1 only) were dissected out and quick frozen on dry ice, and stored at $-80^{\circ} \mathrm{C}$ until processing. In Experiment 1, the hypothalamus for one gonadally intact mouse and one ovariectomized mouse, the hippocampus for one gonadally intact mouse, and the uterus for one gonadally intact mouse and one ovariectomized mouse were damaged and excluded from statistical analysis. In Experiment 2, the hippocampus from one mouse receiving $\mathrm{ICI} 182,780$ was damaged and excluded from statistical analysis. Final samples sizes for all experiments are listed in Tables 1-4. In Experiments 2, 3, and 4, a 1-cm-long segment of the right uterus was dissected out and weighed to confirm ovariectomy status.

Tissue was homogenized in luciferase reporter lysis buffer (Promega) and processed according to manufacturer instructions. Homogenate was flash frozen on dry ice and incubated for $15 \mathrm{~min}$. Samples were then rapidly thawed at $37^{\circ} \mathrm{C}$ and centrifuged for $30 \mathrm{~min}$ at $4900 \times \mathrm{g}$ at $4^{\circ} \mathrm{C}$. Supernatant was collected for luciferase enzyme expression assay and Lowry protein assay.

\section{Luciferase assays}

Luciferase enzyme expression was measured using the Promega Luciferase Assay System. Briefly, $100 \mu \mathrm{l}$ of lu- 
Table 2: Experiment 2 statistics

\begin{tabular}{|c|c|c|c|c|c|c|c|}
\hline Figure & $\begin{array}{l}\text { Statistical } \\
\text { test }\end{array}$ & $\begin{array}{l}\text { Independent } \\
\text { variable (s) }\end{array}$ & $\begin{array}{l}\text { Sample } \\
\text { size }\end{array}$ & Statistics & $\begin{array}{l}\text { Observed } \\
\text { power }\end{array}$ & $\begin{array}{c}\text { Post hoc } \\
\text { comparison } \\
\text { (if applicable) }\end{array}$ & $\begin{array}{l}\text { Post hoc } \\
\text { statistics }\end{array}$ \\
\hline \multirow[t]{6}{*}{3} & $\begin{array}{l}\text { Two-way } \\
\text { ANOVA }\end{array}$ & $\begin{array}{l}\text { Brain region (cortex, } \\
\text { hypothalamus, } \\
\text { hippocampus) } \\
\text { Treatment (Intact }+ \\
\text { aCSF, OVX + aCSF, } \\
\text { OVX + ICI, OVX + Let) }\end{array}$ & $\begin{array}{l}\text { Cortex: } \\
\text { Intact }+ \text { aCSF } n=4 \\
\text { OVX }+ \text { aCSF } n=4 \\
\text { OVX }+ \text { ICI } n=4 \\
\text { OVX + Let } n=4 \\
\text { Hypothalamus: } \\
\text { Intact }+ \text { aCSF } n=4 \\
\text { OVX + aCSF } n=4 \\
\text { OVX + ICI } n=4 \\
\text { OVX + Let } n=4 \\
\text { Hippocampus: } \\
\text { Intact }+ \text { aCSF } n=4 \\
\text { OVX + aCSF } n=4 \\
\text { OVX + ICI } n=3 \\
\text { OVX + Let } n=4\end{array}$ & & & & \\
\hline & & $\begin{array}{r}\text { Main effect of } \\
\text { brain region }\end{array}$ & & $\begin{array}{c}F_{(2,35)}=0.031 \\
p=0.970\end{array}$ & 0.054 & & \\
\hline & & $\begin{array}{l}\text { Main effect of } \\
\text { treatment }\end{array}$ & & $\begin{array}{c}F_{(3,35)}=5.448 \\
\quad * p=0.004\end{array}$ & 0.909 & $\begin{array}{c}\text { Intact }+ \text { aCSF vs } \\
\text { OVX }+ \text { aCSF }\end{array}$ & \\
\hline & & & & & & $\begin{array}{c}\text { OVX }+ \text { aCSF vs } \\
\text { OVX }+I C l\end{array}$ & $* p=0.002$ \\
\hline & & & & & & $\begin{array}{c}\text { OVX }+ \text { aCSF vs } \\
\text { OVX }+ \text { Let }\end{array}$ & $* p=0.030$ \\
\hline & & $\begin{array}{l}\text { Brain region } \times \\
\text { treatment } \\
\text { interaction }\end{array}$ & & $\begin{array}{c}F_{(6,35)}=1.015 \\
p=0.432\end{array}$ & 0.345 & & \\
\hline
\end{tabular}

Let, Letrozole.

*Significant.

ciferase assay substrate was added to $20 \mu \mathrm{l}$ of sample, and the resulting light intensity generated by the lysate was measured by luminometer (PerkinElmer) in triplicate. This process was then repeated using samples in the reverse order to account for signal decay over the course of luminometer readings. Measurements were averaged to obtain the relative light units $(R L U)$, which were normalized to protein concentrations obtained from Lowry protein assays (BCA Protein Assay Kit, Bio-Rad). The final value generated as a measurement of luciferase content was in RLU per microgram of protein (Ciana et al., 2003; Pollard et al., 2018).

\section{Statistical analyses}

Researchers were blind to experimental group during the luciferase assays and statistical analyses. All statistical analyses were conducted using SPSS software (IBM).

Table 3: Experiment 3 statistics

\begin{tabular}{|c|c|c|c|c|c|c|c|}
\hline Figure & $\begin{array}{l}\text { Statistical } \\
\text { test }\end{array}$ & $\begin{array}{l}\text { Independent } \\
\text { variable (s) }\end{array}$ & $\begin{array}{l}\text { Sample } \\
\text { size }\end{array}$ & Statistics & $\begin{array}{l}\text { Observed } \\
\text { power }\end{array}$ & $\begin{array}{c}\text { Post hoc } \\
\text { comparison } \\
\text { (if applicable) }\end{array}$ & $\begin{array}{l}\text { Post hoc } \\
\text { statistics }\end{array}$ \\
\hline \multirow[t]{4}{*}{4} & $\begin{array}{r}\text { Two-way } \\
\text { ANOVA }\end{array}$ & $\begin{array}{l}\text { Brain region (cortex, } \\
\text { hypothalamus, } \\
\text { hippocampus) } \\
\text { Treatment (Intact, OVX) }\end{array}$ & $\begin{array}{l}\text { Cortex: } \\
\text { Intact } n=5 \\
\text { OVX } n=4 \\
\text { Hypothalamus: } \\
\text { Intact } n=5 \\
\text { OVX } n=4 \\
\text { Hippocampus: } \\
\text { Intact } n=5 \\
\text { OVX } n=4\end{array}$ & & & & \\
\hline & & $\begin{array}{r}\text { Main effect of } \\
\text { brain region }\end{array}$ & & $F_{(2,21)}=0.486 ; p=0.622$ & 0.119 & & \\
\hline & & $\begin{array}{l}\text { Main effect of } \\
\text { treatment }\end{array}$ & & $F_{(1,21)}=13.327 ; * p=0.001$ & 0.936 & & \\
\hline & & $\begin{array}{l}\text { Brain region } \times \\
\text { treatment interaction }\end{array}$ & & $F_{(2,21)}=0.486 ; p=0.622$ & 0.119 & & \\
\hline
\end{tabular}

*Significant. 
Table 4: Experiment 4 statistics

\begin{tabular}{|c|c|c|c|c|c|c|c|}
\hline \multirow[t]{3}{*}{5} & $\begin{array}{c}\text { Statistical } \\
\text { test } \\
\text { Two-way } \\
\text { ANOVA }\end{array}$ & $\begin{array}{l}\text { Independent } \\
\text { variable (s) } \\
\text { Brain region (cortex, } \\
\text { hypothalamus, } \\
\text { hippocampus) } \\
\text { Treatment (Intact + } \\
\text { aCSF, OVX + aCSF, } \\
\text { OVX + Let) }\end{array}$ & \begin{tabular}{l}
\multicolumn{1}{c}{$\begin{array}{c}\text { Sample } \\
\text { size }\end{array}$} \\
Cortex: \\
Intact + aCSF $n=7$ \\
OVX + aCSF $n=7$ \\
OVX + Let $n=7$ \\
Hypothalamus: \\
Intact + aCSF $n=7$ \\
OVX + aCSF $n=7$ \\
OVX + Let $n=7$ \\
Hippocampus: \\
Intact + aCSF $n=7$ \\
OVX + aCSF $n=7$ \\
OVX + Let $n=7$
\end{tabular} & Statistics & $\begin{array}{c}\text { Observed } \\
\text { power }\end{array}$ & $\begin{array}{c}\text { Post hoc } \\
\text { comparison } \\
\text { (if applicable) }\end{array}$ & $\begin{array}{l}\text { Post hoc } \\
\text { statistics }\end{array}$ \\
\hline & & $\begin{array}{l}\text { Main effect of } \\
\text { brain region }\end{array}$ & & $\begin{array}{c}F_{(2,54)}=0.220 \\
p=0.804\end{array}$ & 0.083 & & \\
\hline & & $\begin{array}{l}\text { Brain region } \times \\
\text { treatment } \\
\text { interaction }\end{array}$ & & $\begin{array}{c}F_{(4,54)}=0.589 \\
p=0.672\end{array}$ & 0.183 & & \\
\hline
\end{tabular}

Let, Letrozole.

*Significant.

\section{Experiment 1}

Luciferase content in the brain was analyzed by twoway ANOVA with the factors treatment (Intact, OVX) and brain region (cortex, hypothalamus, hippocampus). Luciferase content in the uterus was analyzed by one-way ANOVA with the factor treatment (Intact, OVX).

\section{Experiment 2}

Luciferase content in the brain was analyzed by twoway ANOVA with factors treatment (Intact + aCSF, OVX + aCSF, OVX + letrozole, OVX $+\mathrm{ICl}$ ) and brain region (cortex, hypothalamus, hippocampus). A significant main effect of treatment was probed by the Dunnett's post hoc test, which compares treatments with a single control group (OVX + aCSF).

\section{Experiment 3}

Luciferase content in the brain was analyzed by twoway ANOVA with the factors treatment (Intact, OVX) and brain region (cortex, hypothalamus, hippocampus).

\section{Experiment 4}

Luciferase content in the brain was analyzed by twoway ANOVA with the factors treatment (Intact + aCSF, OVX + aCSF, OVX + letrozole) and brain region (cortex, hypothalamus, hippocampus). A significant main effect of treatment was probed by the Dunnett's post hoc test, which compares treatments with a single control group (OVX + aCSF).

\section{Results}

\section{Experiment 1: impact of short-term ovariectomy on ERE-dependent transcription}

The goal of the first experiment was to test the hypothesis that ERE-dependent transcription levels in the brain are maintained for a short time period following ovariectomy.

As illustrated in Figure $2 A$, there was no main effect of treatment $\left(F_{(1,21)}=0.780, p=0.387\right)$ or brain region $\left(F_{(2,21)}\right.$ $=0.903, p=0.420$ ) on luciferase activity in the brain. As illustrated in Figure $2 B$, there was a nearly significant effect $\left(F_{(1,6)}=5.556, p=0.057\right)$ of treatment in the uterus, with ovariectomy decreasing uterine luciferase activity. Results show that ERE-dependent transcription in the brain, but not in the uterus, is maintained following shortterm ovariectomy.

\section{Experiment 2: impact of aromatase inhibition and estrogen receptor antagonism on ERE-dependent transcription following short-term ovariectomy}

Results of Experiment 1 indicated that ERE-dependent transcription in the brain is not impacted by short-term ovariectomy. The goal of the second experiment was to test the hypothesis that sustained levels of EREdependent transcription in the brain following short-term ovariectomy are due to the actions of neuroestrogens. Additionally, we aimed to confirm the validity of our mouse model by determining whether luciferase activity was blocked by estrogen receptor antagonism.

As illustrated in Figure 3, there was a main effect of treatment $\left(F_{(3,35)}=5.448, p=0.004\right)$. Post hoc analyses revealed that, consistent with the results of Experiment 1, luciferase activity was not impacted by short-term ovariectomy (Intact + aCSF vs OVX + aCSF; $p=0.527$ ). Furthermore, aromatase inhibition via the administration of letrozole significantly decreased luciferase activity following short-term ovariectomy (OVX + aCSF vs OVX + letrozole; $p=0.030$ ). Antagonism of estrogen receptors via the administration of $\mathrm{ICI} 182,780$ significantly de- 

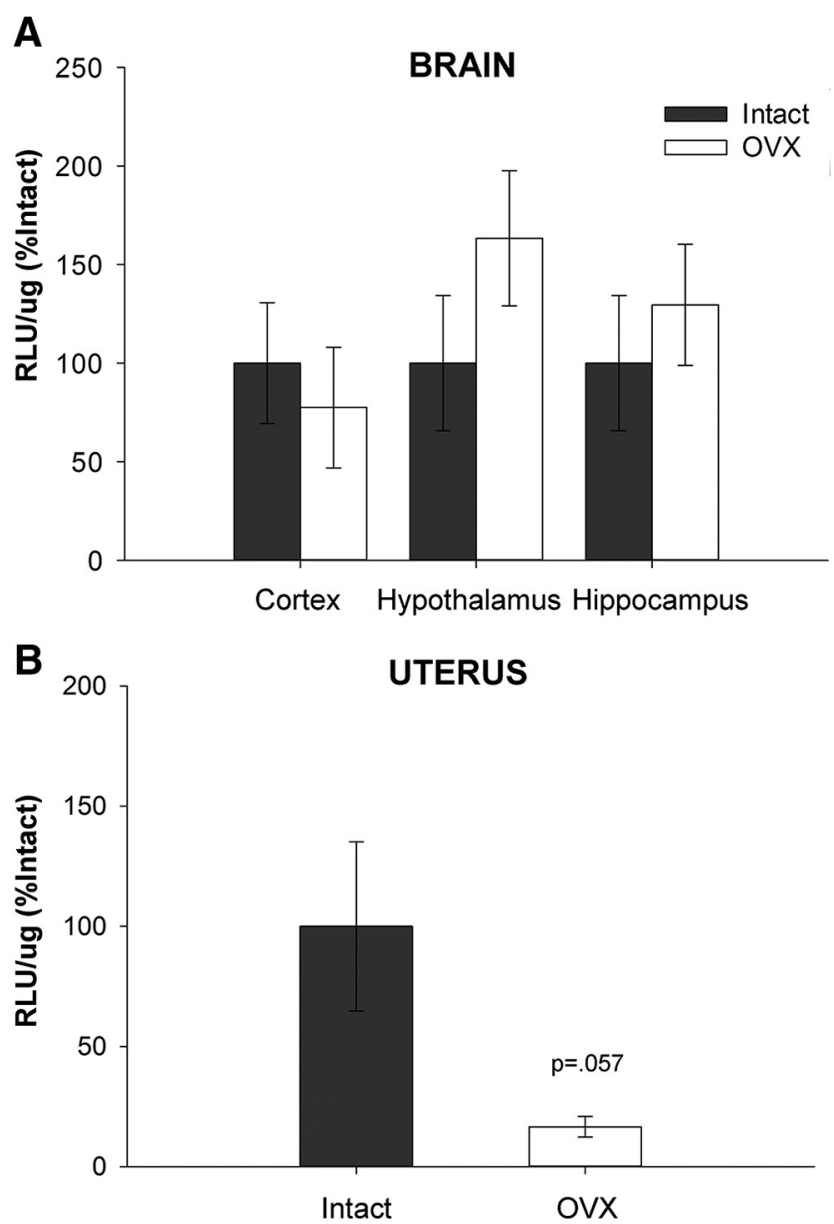

Figure 2. Impact of short-term ovariectomy on ERE-dependent transcription. ERE-Luciferase reporter mice were ovariectomized (OVX) or underwent sham surgery (Intact). Approximately ten days later, mice were killed and luciferase activity was measured in the brain (cortex, hypothalamus, and hippocampus) and uterus. $\boldsymbol{A}$, Short-term ovariectomy had no impact on luciferase activity as measured by relative light units per microgram of protein $(\mathrm{RLU} / \mu \mathrm{g})$ across brain regions. There was no effect of brain region or interaction between treatment and brain region. $\boldsymbol{B}$, Short-term ovariectomy resulted in a near significant $(p=$ .057) decrease in luciferase activity in the uterus. Data are presented as means \pm SEM normalized to percent Intact.

creased luciferase activity compared with ovariectomized control treatment (OVX + aCSF vs OVX $+\mathrm{ICl} ; p=0.002)$. There was no significant effect of brain region $\left(F_{(2,35)}=\right.$ $0.031 ; p=0.970)$ and no significant interaction $\left(F_{(6,35)}=\right.$ $1.015 ; p=0.432$ ) between treatment and brain region. Results indicate that following short-term ovariectomy, the maintenance of ERE-dependent transcriptional activity in the brain is driven by neuroestrogens. Furthermore, they demonstrate the validity of the model in that antagonism of estrogen receptors blocks transcriptional activity.

\section{Experiment 3: impact of long-term ovariectomy on ERE-dependent transcription}

Results of the first two experiments indicated that a short-term loss of ovarian hormones has no impact on

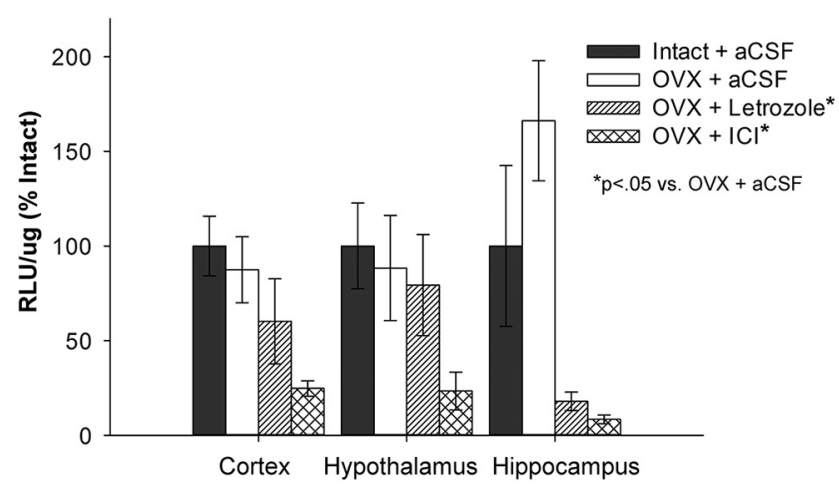

Figure 3. Impact of aromatase inhibition and estrogen receptor antagonism on ERE-dependent transcription following shortterm ovariectomy. ERE-Luciferase reporter mice were ovariectomized (OVX) or underwent sham surgery (Intact). Beginning $\sim 7$ days after surgeries, OVX mice received chronic i.c.v. delivery of vehicle (OVX + aCSF), the aromatase inhibitor letrozole (OVX + Letrozole) or the estrogen receptor antagonist ICI 182,780 (OVX $+(\mathrm{II})$. Intact mice received vehicle (Intact + aCSF). Three days later, mice were killed and luciferase activity was measured in the cortex, hypothalamus, and hippocampus. There was a main effect of treatment $(p<.05)$ on luciferase activity as measured by relative light units per microgram of protein $(\mathrm{RLU} / \mu \mathrm{g})$ across brain regions. Post hoc testing revealed that luciferase activity was not impacted by short-term ovariectomy (OVX + aCSF vs. Intact + aCSF), but was decreased in ovariectomized mice by aromatase inhibition (OVX + aCSF vs. OVX + Letrozole, $p<.05)$ and by estrogen receptor antagonism (OVX + aCSF vs. OVX + $\mathrm{ICI}, p<.05)$. There was no effect of brain region or interaction between treatment and brain region. Data are presented means \pm SEM normalized to percent Intact + aCSF.

levels of ERE-dependent transcription in the brain. Therefore, the goal of Experiment 3 was to test the hypothesis that long-term loss of ovarian function will result in a significant decrease in brain levels of ERE-dependent transcription.

As illustrated in Figure 4, there was a main effect of treatment $\left(F_{(1,21)}=13.327 ; p=0.001\right)$, indicating that long-term ovariectomy significantly decreases luciferase activity in the brain compared with gonadally intact controls. There was no effect of brain region $\left(F_{(2,21)}=0.486\right.$; $p=0.622)$ and no interaction $\left(F_{(2,21)}=0.486 ; p=0.622\right)$ between treatment and brain region. Despite the significant decrease in luciferase activity in the brain following long-term ovariectomy, some residual transcriptional activity was evident in all three brain regions $70 \mathrm{~d}$ after the loss of ovarian function.

\section{Experiment 4: impact of aromatase inhibition on ERE-dependent transcription following long-term ovariectomy}

Results of Experiment 3 indicate that long-term ovarian hormone deprivation attenuates but does not completely block ERE-dependent transcription in the brain. The goal of the final experiment was to explore the contributions of neuroestrogens to the residual ERE-dependent transcriptional activity evident following long-term loss of ovarian hormones. Because the model was validated as being dependent on estrogen receptors in Experiment 2, the ICI 


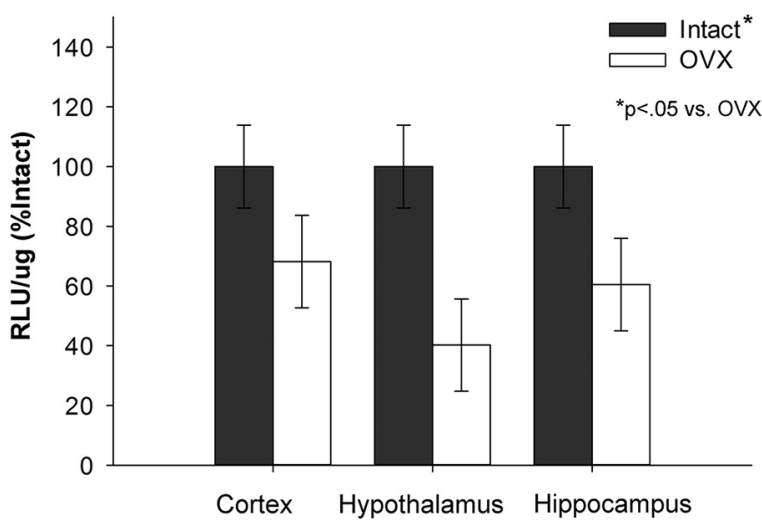

Figure 4. Impact of long-term ovariectomy on ERE-dependent transcription. ERE-Luciferase reporter mice were ovariectomized (OVX) or underwent sham surgery (Intact). Approximately 70 days later, mice were killed and luciferase activity was measured in the cortex, hypothalamus, and hippocampus. Long-term ovariectomy significantly decreased luciferase activity as measured by relative light units per microgram of protein $(R L U / \mu g)$ across brain regions $(p<.05)$. There was no effect of brain region or interaction between treatment and brain region. Data are presented as means \pm SEM normalized to percent Intact.

182,780 treatment group was not included in this final experiment.

As illustrated in Figure 5, there was a main effect of treatment $\left(F_{(2,54)}=5.785 ; p=0.005\right)$. Post hoc analyses revealed that, consistent with the results of Experiment 3,

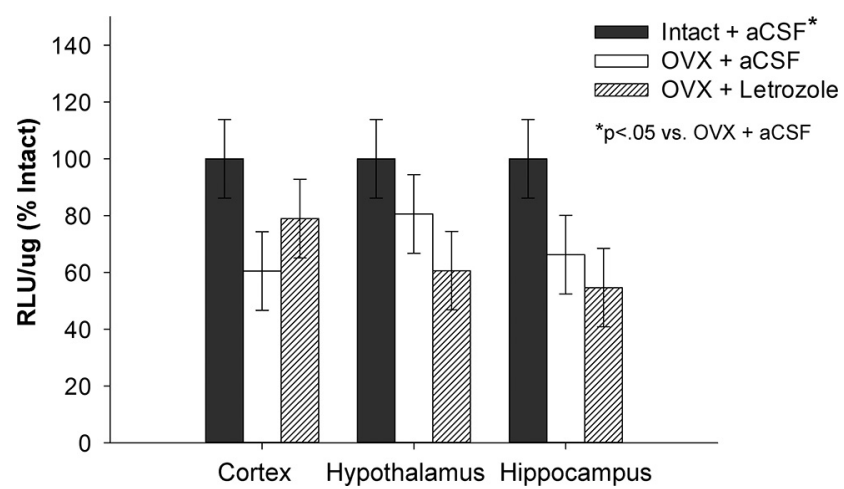

Figure 5. Impact of aromatase inhibition on ERE-dependent transcription following long-term ovariectomy. ERE-Luciferase reporter mice were ovariectomized (OVX) or underwent sham surgery (Intact). Beginning $\sim 70$ days after surgeries, OVX mice received chronic i.c.v. delivery of vehicle (OVX + aCSF), or the aromatase inhibitor letrozole (OVX + Letrozole). Intact mice received vehicle (Intact + aCSF). Three days later, mice were killed and luciferase activity was measured in the cortex, hypothalamus, and hippocampus. There was a main effect of treatment $(p<.05)$ on luciferase activity as measured by relative light units per microgram of protein (RLU/ $\mu \mathrm{g}$ ) across brain regions. Post hoc testing revealed that luciferase activity was significantly decreased following long-term ovariectomy (OVX + aCSF vs. Intact + aCSF, $p<.05$ ), but was not impacted by aromatase inhibition in ovariectomized mice (OVX + aCSF vs. OVX + Letrozole). There was no effect of brain region or interaction between treatment and brain region. Data are presented as means \pm SEM normalized to percent Intact + aCSF. luciferase activity was decreased following long-term ovariectomy (Intact + aCSF vs OVX + aCSF; $p=0.016$ ). Aromatase inhibition via the administration of letrozole did not impact luciferase activity following long-term ovariectomy compared with ovariectomized control treatment (OVX + aCSF vs OVX + letrozole; $p=0.898)$. There was no significant effect of brain region $\left(F_{(2,54)}=0.220 ; p=\right.$ $0.804)$ and no significant interaction $\left(F_{(4,54)}=0.589 ; p=\right.$ 0.672 ) between treatment and brain region. Results indicate that neuroestrogens do not contribute to the residual ERE-dependent transcription evident following long-term ovariectomy.

\section{Discussion}

Results of the present study indicate that EREdependent transcription in the brain continues after the loss of ovarian hormones, and that brain-derived estradiol mediates that transcriptional activity for at least a limited period of time following ovariectomy. Specifically, we showed that ERE-dependent transcription in the cortex, hypothalamus, and hippocampus is sustained at least 10 d after ovariectomy. Seventy days after ovariectomy, ERE-dependent transcription significantly decreases in the brain, although some residual activity remains. Furthermore, we showed that intracerebroventricular administration of the aromatase inhibitor letrozole attenuates ERE-dependent transcription in the brain following shortterm, but not long-term, ovariectomy. Collectively, these data reveal that neuroestrogens impact ERE-dependent transcription for only a limited time window after the loss of ovarian hormones.

In Experiments 1 and 2, we showed that there was no decrease in ERE-dependent transcription in any of the brain regions analyzed $10 \mathrm{~d}$ after ovariectomy, a time point at which ovarian estrogens are no longer circulating throughout the body (Woolley and McEwen, 1993). We showed a nearly significant decrease in ERE-dependent transcription in the uterus at the same time point-consistent with previous work using the ERE-Luc mouse model (Ciana et al., 2003)-indicating that this maintained transcription is specific to the brain. To understand the mechanism through which transcription in the brain is maintained, we administered the aromatase inhibitor letrozole to the brain to block neuroestrogen synthesis. Blocking neuroestrogen synthesis resulted in a significant decrease in ERE-dependent transcription following shortterm ovariectomy. Current results indicate that this decrease occurs across brain areas, as revealed by a statistical main effect of treatment and a lack of an interactive effect of treatment and brain area. However, the effect of letrozole on transcription is numerically larger in the hippocampus than it is in the cortex and hypothalamus. Future experiments with a larger sample size and thus more statistical power could reveal differential effects across brain areas.

The present results are consistent with the current literature on neuroestrogens in short-term ovariectomized animal models, which predominately has been focused on the hippocampus. For example, letrozole administration negatively impacted memory consolidation (Tuscher 
et al., 2016) and hippocampal spine synaptic density (Zhou et al., 2010) in recently ovariectomized mice and changed serotonergic and catecholaminergic turnover rates in the hippocampus and prefrontal cortex of ovariectomized rats (Kokras et al., 2018). Aromatase activity has been documented in several brain regions, including the hypothalamus and cerebral cortex (Naftolin et al., 1996; Azcoitia et al., 2011; Stanić et al., 2014; Tabatadze et al., 2014). However, the hippocampus is the only region of the adult mammalian brain in which there is direct evidence of de novo estradiol synthesis (Prange-Kiel et al., 2003), although there is indication of de novo estradiol synthesis in the cerebellum of the developing brain as well (Amateau et al., 2004). Interestingly, hippocampal levels of estradiol exceed plasma levels of circulating estradiol (Kato et al., 2013). Together with these previous studies, our findings emphasize the importance of neuroestrogens in hippocampal function after recent loss of ovarian hormones. More extensive examination of the impact of neuroestrogens on other brain regions is warranted.

The results of the current experiments demonstrate for the first time a direct connection between brain-derived estradiol and ERE-dependent transcription in vivo. Locally produced estrogens in the brain have been proposed to act as neurotransmitters in a rapid manner (Balthazart et al., 2001). Neuroestrogens influence synaptic plasticity in the hippocampus by initiating nongenomic actions of membrane estrogen receptors, particularly estrogen receptor $\alpha$ (Ishii et al., 2007; Wang et al., 2018). Our results show that inhibition of estradiol synthesis in the brain results in a decrease in ERE-dependent transcription, demonstrating a role for neuroestrogen regulation of the genomic effects of estrogen receptors in addition to the established nongenomic membrane effects. These findings are consistent with the previously suggested hypothesis (Cornil, 2018; Vajaria and Vasudevan, 2018) that the activation of membrane estrogen receptors by neuroestrogens may ultimately lead to transcriptional activity of nuclear estrogen receptors through the activation of various signaling cascades.

In Experiments 3 and 4, we showed that EREdependent transcription in the brain decreases after longterm ovariectomy. Estrogen receptor expression in the brain changes after long periods of ovarian hormone deprivation (Bohacek and Daniel, 2009), which likely contributes to this decline in transcriptional activity. Although ERE-dependent transcription significantly decreased in brains of long-term ovariectomized mice, there remained residual activity. Thus, estrogen receptor activity persists even after prolonged ovarian hormone deprivation and likely subsequent changes in estrogen receptor expression in the brain. However, in contrast to the effects seen following short-term ovariectomy, the inhibition of aromatase activity via letrozole did not block residual transcriptional activity after long-term ovariectomy. Therefore, results indicate that remaining transcriptional activity following long-term ovarian hormone deprivation is not mediated by neuroestrogens. To our knowledge, this duration of ovarian hormone deprivation is the longest at which neuroestrogen activity has been tested in rodents. Previous work showed an effect of letrozole on hippocampal spine density in rats at 4 weeks after ovariectomy (Zhou et al., 2010), a time point in between our short-term and long-term paradigms. Future studies should investigate the time course of the decline of neuroestrogen activity following ovariectomy. Nevertheless, these results indicate that there is a point at which neuroestrogens no longer mediate estrogen receptor transcriptional activity following the loss of ovarian function.

This observed decline in neuroestrogen activity following long-term ovariectomy is consistent with previous literature indicating that systemic estrogens are necessary to regulate estradiol synthesis in the brain. Systemic estrogens regulate $\mathrm{GnRH}$ release by providing feedback at the level of the hypothalamus (Clarke and Cummins, 1987), which in turn regulates neuroestrogen synthesis in the hippocampus (Prange-Kiel et al., 2013). The administration of $\mathrm{GnRH}$ to the hippocampus reverses the loss of spines (Prange-Kiel et al., 2013) and memory impairment (Nelson et al., 2016) associated with aromatase inhibition. A recent study using the newly validated ultraperformance liquid chromatography-tandem mass spectrometry method of measuring estradiol content showed that the brains of female rats have higher levels of estradiol in the hippocampus, amygdala, and preoptic area than in blood serum $24 \mathrm{~h}$ after ovariectomy (Li and Gibbs, 2019). Importantly, systemic estradiol treatment increases levels of estradiol in the brain in a dose-dependent manner, but this effect was blocked by systemic letrozole injections. These studies indicate a mechanism through which systemic estrogen regulates neuroestrogen synthesis in the brain in a dose-dependent manner via $\mathrm{GnRH}$ signaling. Previous work also demonstrated that letrozole administration following long-term ovariectomy did not result in the same memory impairment shown in the presence of circulating estrogens (Nelson et al., 2016). Collectively, results suggest that prolonged ovarian hormone deprivation would result in a loss of regulation of neuroestrogen synthesis, which could explain why neuroestrogens no longer mediate estrogen receptor activity after long-term ovariectomy.

Because we observed residual ERE-dependent transcription following long-term ovariectomy that was not impacted by letrozole treatment, we can conclude that other mechanisms must be mediating this transcription. Growth factors such as insulin-like growth factor-1 (IGF-1) can influence estrogen receptor-dependent transcription in a ligand-independent manner by activating signaling pathways that lead to phosphorylation of estrogen receptors (Smith, 1998). Estrogen receptors and IGF-1 receptors colocalize in cells in the female rodent brain (Cardona-Gómez et al., 2000), and the administration of IGF-1 to the brains of ovariectomized rats results in increased phosphorylation of estrogen receptor $\alpha$ at serine-118 (Grissom and Daniel, 2016). This ligand-independent mechanism is presumed to be independent not only from ovarian estrogens, but from neuroestrogens as well. However, recent results show that in vitro some aromatase activity is necessary for IGF-1 activation of estrogen receptors to occur 
in the Neuro-2A cell line (Pollard and Daniel, 2019). In the current studies, inhibition of aromatase activity did not impact what is likely ligand-independent activation of estrogen receptors following long-term ovariectomy in vivo. These seemingly contradictory observations may be explained by inherent differences in the rapid ligandindependent activation of estrogen receptors in vitro and long-term modulation of estrogen receptor function after a prolonged absence of available ligands. Future studies should investigate the interaction between neuroestrogen activity and ligand-independent activation of estrogen receptors in vivo.

The results of the current experiments are consistent with previous studies using the ERE-Luciferase reporter mouse model. Earlier studies validating this model demonstrated that luciferase activity is sensitive to estradiol levels in a tissue-specific manner, that the inhibition of estrogen receptors with $\mathrm{ICI} 182,780$ successfully blocks luciferase expression, and that some luciferase activity is still detectable in the brains of ovariectomized adult mice (Ciana et al., 2001, 2003; Stell et al., 2008). Importantly, the current study expands on previous work by implicating neuroestrogens in ERE-dependent transcription in the brain following short-term ovariectomy and by showing that luciferase expression is decreased in the cortex, hypothalamus, and hippocampus following long-term ovariectomy.

Overall, the results of the current experiments indicate that regulation of estrogen receptor dependent transcription in the brain changes following prolonged periods of ovarian hormone deprivation, such as menopause in humans. However, several studies in humans and nonhuman primates suggest that neuroestrogens may still play a role in cognition after menopause. For example, longterm systemic letrozole treatment impaired performance on a hippocampal-dependent memory task in postmenopausal women (Bayer et al., 2015), and in gonadectomized male and female marmosets 4 weeks of systemic letrozole treatment impaired performance on a spatial memory task (Gervais et al., 2019). Interestingly, this latter study also showed an increase in hippocampal estradiol levels in the letrozole-treated marmosets, suggesting a potential rebound effect on neuroestrogen synthesis following long-term letrozole exposure. Whereas these findings may appear inconsistent with the results of the current study - which suggest that the role of neuroestrogens in cognition declines after loss of ovarian functionthe inconsistencies may reveal a mechanistic difference in the methods of aromatase inhibition used. Gervais et al. (2019) used a model of long-term systemic letrozole administration based on the regimen frequently used by postmenopausal women with breast cancer, such as those tested in the study by Bayer et al. (2015). Systemic letrozole administration is able to influence the brain by crossing the blood-brain barrier (Dave et al., 2013), but it may also result in changes in peripheral steroid hormone synthesis in adipose or adrenal tissues. On the other hand, the relatively shorter, brain-specific administration of letrozole used in rodent studies, including the present work, is less likely to influence these peripheral tissues.
Additionally, a metareview of the literature regarding the effects of endocrine therapies in postmenopausal women revealed mixed findings on the impact of aromatase inhibitors on cognition (Lee et al., 2016), illustrating the complexity of effects of long-term aromatase inhibition on the brain.

The results of the current work point to a continued role for estrogen receptor activation in the brain after loss of ovarian function. Together with other studies, they suggest a potential alternative route for combatting postmenopausal cognitive decline. Previous work has shown that viral-vector-mediated upregulation of estrogen receptor (ER) $\alpha$ in the hippocampi of aging ovariectomized rats enhances memory in the absence of circulating estrogens (Witty et al., 2012). In hippocampal cultures, it has been shown that the administration of an $\mathrm{ER} \alpha$ agonist increases spine density, even in the presence of letrozole (Zhou et al., 2010). Other previous work has shown that estrogen receptors in the brain remain transcriptionally active in the absence of ovarian or exogenously delivered estrogens (Pollard et al., 2018). We have now expanded these results to show that estrogen receptors can activate transcription in the brain in the absence of brain-derived estrogens, as well. Overall, these studies represent an increasing body of literature that suggests an important role for estrogen receptors-independent from estrogens-in maintaining cognitive health in the aging female brain.

\section{References}

Amateau S, Alt J, Stamps C, McCarthy M (2004) Brain estradiol content in newborn rats: sex differences, regional heterogeneity, and possible de novo synthesis by the female telencephalon. Endocrinology 145:2906-2917.

Azcoitia I, Yague J, Garcia-Segura L (2011) Estradiol synthesis within the human brain. Neuroscience 191:139-147.

Balthazart J, Baillien M, Ball G (2001) Rapid and reversible inhibition of brain aromatase activity. J Neuroendocrinol 13:63-73.

Barker J, Galea L (2009) Sex and regional differences in estradiol content in the prefrontal cortex, amygdala and hippocampus of adult male and female rats. Gen Comp Endocrinol 164:77-84.

Bayer J, Rune G, Schultz H, Tobia MJ, Mebes I, Katzler O, Sommer $T$ (2015) The effect of estrogen synthesis inhibition on hippocampal memory. Psychoneuroendocrinology 56:213-225.

Bean LA, lanov L, Foster TC (2014) Estrogen receptors, the hippocampus, and memory. Neuroscientist 20:534-545.

Bohacek J, Daniel JM (2009) The ability of oestradiol administration to regulate protein levels of oestrogen receptor alpha in the hippocampus and prefrontal cortex of middle-aged rats is altered following long-term ovarian hormone deprivation. J Neuroendocrinol 21:640-647.

Byers SL, Wiles MV, Dunn SL, Taft RA (2012) Mouse estrous cycle identification tool and images. PLoS One 7:e35538.

Cardona-Gómez G, DonCarlos L, Garcia-Segura L (2000) Insulin-like growth factor I receptors and estrogen receptors colocalize in female rat brain. Neuroscience 99:751-760.

Ciana P, Di Luccio G, Belcredito S, Pollio G, Vegeto E, et al. (2001) Engineering of a mouse for the in vivo profiling of estrogen receptor activity. Mol Endocrinol 15:1104-1113.

Ciana P, Raviscioni M, Mussi P, Vegeto E, Que I, et al. (2003) In vivo imaging of transcriptionally active estrogen receptors. Nat Med 9:82.

Clarke IJ, Cummins JT (1987) Pulsatility of reproductive hormones: physiological basis and clinical implications. Baillieres Clin Endocrinol Metab 1:1-21. 
Cornil CA (2018) On the role of brain aromatase in females: why are estrogens produced locally when they are available systemically? J Comp Physiol A Neuroethol Sens Neural Behav Physiol 204:3149.

Daniel JM, Witty CF, Rodgers SP (2015) Long-term consequences of estrogens administered in midlife on female cognitive aging. Horm Behav 74:77-85.

Dave N, Gudelsky G, Desai P (2013) The pharmacokinetics of letrozole in brain and brain tumor in rats with orthotopically implanted C6 glioma, assessed using intracerebral microdialysis. Cancer Chemother Pharmacol 72:349-357.

Gervais N, Remage-Healey L, Starrett J, Pollak D, Mong J, Lacreuse A (2019) Adverse effects of aromatase inhibition on the brain and behavior in a nonhuman primate. J Neurosci 39:918-928.

González M, Cabrera-Socorro A, Pérez-García CG, Fraser JD, López FJ, Alonso R, Meyer G (2007) Distribution patterns of estrogen receptor alpha and beta in the human cortex and hippocampus during development and adulthood. J Comp Neurol 503:790-802.

Grissom EM, Daniel JM (2016) Evidence for ligand-independent activation of hippocampal estrogen receptor- $\alpha$ by IGF-1 in hippocampus of ovariectomized rats. Endocrinology 157:3149-3156.

Hyder S, Chiappetta C, Stancel G (1999) Interaction of human estrogen receptors alpha and beta with the same naturally occurring estrogen response elements. Biochem Pharmacol 57:597-601.

Ishii $\mathrm{H}$, Tsurugizawa T, Ogiue-Ikeda M, Asashima M, Mukai $\mathrm{H}$, Murakami G, Hojo Y, Kimoto T, Kawato S (2007) Local production of sex hormones and their modulation of hippocampal synaptic plasticity. Neuroscientist 13:323-334.

Kato A, Hojo Y, Higo S, Komatsuzaki Y, Murakami G, Yoshino H, Uebayashi M, Kawato S (2013) Female hippocampal estrogens have a significant correlation with cyclic fluctuation of hippocampal spines. Front Neural Circuits 7:149.

Kenealy B, Kapoor A, Guerriero K, Keen K, Garcia J, Kurian JR, Ziegler TE, Terasawa E (2013) Neuroestradiol in the hypothalamus contributes to the regulation of gonadotropin releasing hormone release. J Neurosci 33:19051-19059.

Kokras N, Pastromas N, Papasava D, de Bournonville C, Cornil C, Dalla C (2018) Sex differences in behavioral and neurochemical effects of gonadectomy and aromatase inhibition in rats. Psychoneuroendocrinology 87:93-107.

Korol DL, Pisani SL (2015) Estrogens and cognition: friends or foes? An evaluation of the opposing effects of estrogens on learning and memory. Horm Behav 74:105-115.

Kretz O, Fester L, Wehrenberg U, Zhou L, Brauckmann S, Zhao S, Prange-Kiel J, Naumann T, Jarry H, Frotscher M, Rune GM (2004) Hippocampal synapses depend on hippocampal estrogen synthesis. J Neurosci 24:5913-5921.

Lai Y-J, Yu D, Zhang JH, Chen G-J (2017) Cooperation of genomic and rapid nongenomic actions of estrogens in synaptic plasticity. Mol Neurobiol 54:4113-4126.

Lee PE, Tierney MC, Wu W, Pritchard KI, Rochon PA (2016) Endocrine treatment-associated cognitive impairment in breast cancer survivors: evidence from published studies. Breast Cancer Res Treat 158:407-420.

Li J, Gibbs RB (2019) Detection of estradiol in rat brain tissues: contribution of local versus systemic production. Psychoneuroendocrinology 102:84-94.

Luine V (2014) Estradiol and cognitive function: past, present and future. Horm Behav 66:602-618.

Luine V, Serrano P, Frankfurt M (2018) Rapid effects on memory consolidation and spine morphology by estradiol in female and male rodents. Horm Behav 104:111-118.

Mitra SW, Hoskin E, Yudkovitz J, Pear L, Wilkinson HA, Hayashi S, Pfaff DW, Ogawa S, Rohrer SP, Schaeffer JM, McEwen BS, Alves
SE (2003) Immunolocalization of estrogen receptor beta in the mouse brain: comparison with estrogen receptor alpha. Endocrinology 144:2055-2067.

Naftolin F, Horvath T, Jakab R, Leranth C, Harada N, Balthazart J (1996) Aromatase immunoreactivity in axon terminals of the vertebrate brain. An immunocytochemical study on quail, rat, monkey and human tissues. Neuroendocrinology 63:149-155.

Nelson BS, Black KL, Daniel JM (2016) Circulating estradiol regulates brain-derived estradiol via actions at $\mathrm{GnRH}$ receptors to impact memory in ovariectomized rats. eNeuro 3:ENEURO.0321-16.2016.

Pollard KJ, Daniel JM (2019) Nuclear estrogen receptor activation by insulin-like growth factor-1 in Neuro-2A neuroblastoma cells requires endogenous estrogen synthesis and is mediated by mutually repressive MAPK and PI3K cascades. Mol Cell Endocrinol 490:68-79

Pollard KJ, Wartman HD, Daniel JM (2018) Previous estradiol treatment in ovariectomized mice provides lasting enhancement of memory and brain estrogen receptor activity. Horm Behav 102: $76-84$.

Prange-Kiel J, Wehrenberg U, Jarry H, Rune GM (2003) Para/autocrine regulation of estrogen receptors in hippocampal neurons. Hippocampus 13:226-234.

Prange-Kiel J, Schmutterer T, Fester L, Zhou L, Imholz P, Brandt N, Vierk R, Jarry H, Rune GM (2013) Endocrine regulation of estrogen synthesis in the hippocampus? Prog Histochem Cytochem 48:4964.

Shughrue P, Lane M, Merchenthaler I (1997) Comparative distribution of estrogen receptor-alpha and -beta mRNA in the rat central nervous system. J Comp Neurol 388:507-525.

Smith CL (1998) Cross-talk between peptide growth factor and estrogen receptor signaling pathways. Biol Reprod 58:627-632.

Stanić D, Dubois S, Chua H, Tonge B, Rinehart N, Horne MK, Boon WC (2014) Characterization of aromatase expression in the adult male and female mouse brain. I. coexistence with oestrogen receptors $\alpha$ and $\beta$, and androgen receptors. PLoS One 9:e90451.

Stell A, Belcredito S, Ciana P, Maggi A (2008) Molecular imaging provides novel insights on estrogen receptor activity in mouse brain. Mol Imaging 7:283-292.

Tabatadze N, Sato S, Woolley CS (2014) Quantitative analysis of long-form aromatase mRNA in the male and female rat brain. PLoS One 9:e100628.

Tuscher J, Szinte J, Starrett J, Krentzel A, Fortress A, et al. (2016) Inhibition of local estrogen synthesis in the hippocampus impairs hippocampal memory consolidation in ovariectomized female mice. Horm Behav 83:60-67.

Vajaria R, Vasudevan N (2018) Is the membrane estrogen receptor, GPER1, a promiscuous receptor that modulates nuclear estrogen receptor-mediated functions in the brain? Horm Behav 104:165172.

Wang W, Le AA, Hou B, Lauterborn JC, Cox C, Levin ER, Lynch G, Gall CM (2018) Memory-related synaptic plasticity is sexually dimorphic in rodent hippocampus. J Neurosci 38:7935-7951.

Witty CF, Foster TC, Semple-Rowland SL, Daniel JM (2012) Increasing hippocampal estrogen receptor alpha levels via viral vectors increases MAP kinase activation and enhances memory in aging rats in the absence of ovarian estrogens. PLoS One 7:e51385.

Woolley CS, McEwen BS (1993) Roles of estradiol and progesterone in regulation of hippocampal dendritic spine density during the estrous cycle in the rat. J Comp Neurol 336:293-306.

Zhou L, Fester L, von Blittersdorff B, Hassu B, Nogens H, PrangeKiel J, Jarry H, Wegscheider K, Rune GM (2010) Aromatase inhibitors induce spine synapse loss in the hippocampus of ovariectomized mice. Endocrinology 151:1153-1160. 